\title{
GEORGE S. EASTWOOD
}

1878-1953

By the death of George S. Eastwood the Society has lost one of its most loyal, devoted and enthusiastic members. Mr Eastwood was a schoolmaster by profession, and it was as one of his pupils that I first met him. Although he was English by birth and a graduate of London University, his teaching career was spent almost entirely in Scotland, firstly as an assistant master at Arbroath High School, and then, from 1911 until his retirement in 1938, as Principal Teacher of Mathematics in Beath High School, Cowdenbeath.

He was an able teacher, a strict, but never harsh, disciplinarian. He did not court popularity, for that was not his way, and a certain shyness and reserve of manner made him appear difficult of approach; and yet withal he won the healthy respect of his students, and I have still to meet the former pupil who does not speak of him with affection. They remember the conscientious work he did, but perhaps most of all they recall his unbounded enthusiasm for his subject, for no pupil who was mathematically inclined could fail to be infected by it.

Mathematics was at once his work, his hobby, and his first love, and his pursuit of it led him to membership of the Edinburgh Mathematical Society; he was also a Fellow of the Royal Society of Edinburgh. His membership of these Societies was no nominal one, and at one time he was a prominent member of the Mathematical Society. On at least two occasions he read papers before it, and he contributed the results of his private researches to its Mathematical Notes.

$\mathrm{Mr}$ Eastwood was not prepared to keep mathematics to himself, and he, with a few other enthusiasts, in the early twenties founded the Beath Scientific Society, a society which flourished for quite a number of years, and one to which he himself read many papers, and whose mathematical expert he undoubtedly was.

One did not make friends easily with $\mathrm{Mr}$ Eastwood, but those who were his friends discovered in him a kindly disposition, a whimsical sense of humour, and a true Christian spirit, for he was prepared to do a good turn whenever he could. At least, that was my experience.

No account of $\mathrm{Mr}$ Eastwood would be complete without a reference to cricket, for if mathematics was his first love, undoubtedly cricket was his second, and that thoroughness which he displayed in his work, he carried into his play. He was associated in turn with clubs at South Shields, Arbroath and Cowdenbeath, where he was captain for some years, and on occasion was called upon to play for Fife in county cricket.

It was with genuine regret and a deep sense of personal loss that those who knew Mr Eastwood learned of his death, and with his passing they feel that they have lost an esteemed and valued friend.

A. Waterson. 